\title{
Article
}

\section{Cameron McEwan on the 'difficult whole' as a critical strategy - The Difficult Whole: A Reference Book on Robert Venturi, John Rauch, and Denise Scott Brown Edited and with contributions by Kersten Geers, Jelena Pančevac, and Andrea Zanderigo With photographs by Bas Princen. Switzerland, Park Books, 2016 216pp. Out of print}

McEwan, Cameron

Available at http://clok.uclan.ac.uk/25735/

McEwan, Cameron ORCID: 0000-0002-0683-1708 (2019) Cameron McEwan on the 'difficult whole' as a critical strategy - The Difficult Whole: A Reference Book on Robert Venturi, John Rauch, and Denise Scott Brown Edited and with contributions by Kersten Geers, Jelena Pančevac, and Andrea Zanderigo With photographs by Bas Princen. Switzerland, Park Books, 2016 216pp. Out of print. arq: Architectural Research Quarterly, 22 (3). pp. 260-263. ISSN 13591355

It is advisable to refer to the publisher's version if you intend to cite from the work. http://dx.doi.org/10.1017/S135913551800060X

For more information about UCLan's research in this area go to http://www.uclan.ac.uk/researchgroups/ and search for <name of research Group>.

For information about Research generally at UCLan please go to http://www.uclan.ac.uk/research/ All outnuts in CI_oK are orotected_bv Intellectual Pronerty Riohts law includino

CLoK

Central Lancashire online Knowledge www.clok.uclan.ac.uk 


\section{CLoK}

Central Lancashire online Knowledge www.clok.uclan.ac.uk 

strategy

\title{
Title: The Difficult Whole: A Reference Book on Robert Venturi, John Rauch and Denise Scott Brown
}

\author{
Cameron McEwan
}

In the concluding chapter of Complexity and Contradiction in Architecture (New York: Museum of Modern Art, [1966] 2002) Robert Venturi writes about the notion of the difficult whole: On one level, the difficult whole is a formal and compositional strategy at the scale of architecture focused on the organisation of diverse elements, contradictory forms and opposing scales in the plan and façade. On an urban level, the difficult whole is a reading of how architecture develops a form or counter form within the ideological field of the city. On a last level, the difficult whole is critical thought. It is a strategy to negotiate conflicting desires, architecture and the city, analysis and project, site and programme, form and history, architect and client, and the difficulty of defining a coherent whole. Venturi termed this a "difficult whole," because "the whole is difficult to achieve."

\section{Formal Knowledge}

In this beautifully produced, straightforward yet polemical monograph, editors Kersten Geers, Jelena Pančevac and Andrea Zanderigo articulate Venturi's “difficult whole" as a critical strategy for contemporary architecture. The book is part of a larger project to rethink the work of architects of Venturi's generation, including Giorgio Grassi, Aldo Rossi and James Stirling, all of whom have been the subject of previous critique by the editors: In Two Essays on Architecture (Zürich: Kommode Verlag, 2014), Zanderigo and his firm Baukuh discuss the analytical procedure that Grassi and Rossi adopt, analyse the relations of type, form, authorship and the connection between architecture and the city, leading toward a critical appreciation of architecture as collective knowledge. In $O A S E 79$ (2009), a special issue on Stirling, Geers defines Stirling's approach to architecture as a "non-dogmatic accumulation of formal knowledge," which exemplifies a set of formal operations for an analytical and generative approach that brings together historical references, combining and recombining past architecture into legible spatial forms in precise compositions so that architecture speaks of its own accumulated language.

Grassi, Rossi, Stirling and Venturi share similar traits. They are cultured and authorial architects who produced thought provoking projects based on a close-reading and deep engagement with the history of architecture and the city, and whose buildings, drawings and texts are important reference points to be rethought to address the often weak architectural discourse today. Where Stirling explored and catalogued architecture's formal knowledge in the famous worm's-eye axonometric drawings 
showing how separate spatial forms relate and are organised, Venturi accumulated historical references and presented them as visual collections of buildings and building fragments in the pages of Complexity and Contradiction. Each building or fragment itself becomes a repertoire of syntactic elements to be abstracted, transformed and rearticulated in future projects.

\section{Series}

The book opens and closes with a series of polychromatic perspective drawings of selected buildings by Venturi, Rauch and Scott Brown and three additional buildings by Alvaro Siza, Stirling and Wilford, and Kazunari Sakamoto. The perspectives, indebted to Ed Ruscha's paintings from Course of Empire, have an otherworldly appearance in the way the image is constructed - each building is positioned on the horizon, displaced from its context, with the front façade flat against the picture plane, the ground implied by a colour gradient that fades toward the top of the page, and the larger part of the image occupied by a hazy sky.

Abstracted along similar lines, another visual component of the book is a suite of photographs by Bas Princen which show The Vanna Venturi House, Fire Station Number 4 and the Lewis Thomas Laboratory. The photographs are unpeopled and mostly focused on close-up surfaces or fragments such as a return in the wall, a seat, a window. Princen's photographs are situated somewhere between a documentation of the buildings as autonomous forms and poetic suggestions toward the possible forms of life that the buildings frame.

One way to read this architecture without context is to read it in relation to a statement by the editors in their introduction: "Architecture deals with itself." Architecture produces its own context. A context that is internal to the discipline and internal to the work of a given architect. This notion of internal consistency, of series, forces an engagement in the work at hand defined on its own terms and with its own claims. As Geers has said in "Words Without Thoughts Never to Heaven Go" (2G, Barcelona: Gustavo Gili, 2012): "Only in the accumulation of projects - as a series - can a specific argument about architecture and its principles be made."

Such a series forms the core of The Difficult Whole, which chronologically organises 28 buildings by Venturi, Rauch and Scott Brown, from the 1959 Beach House in New Jersey to the Sainsbury Wing extension of the National Gallery in London (19851991). The majority of projects are credited to Venturi and Rauch, and it is unfortunate that there is little space given to Scott Brown's contribution, in particular her urban thought. The Scott Brown era, known for the studies of Levittown and Las Vegas, is characterized by a sociological dimension and a shift from issues of "form" to "sign." It seems that if work of this period were to be included in this monograph, the polemical intent of the editors would be put at stake - an emphasis on architecture as formal knowledge. The selection of projects focuses on the period of the 1960s, including built and unbuilt work. These range in scale from the very small Haas Garage (1963-64), a timber clad cube with arched porch and arched windows, to the very large Transportation Square Office Building (1967-69), a competition entry organised as a $120 \mathrm{~m}$ nine-storey slab, that steps down to a three-storey mat-type volume, cut diagonally and enclosing an entrance court. Each project is introduced with a short text followed by archive photographs and study drawings, plans and sections (but no site plans), which have been redrawn in a common graphic language. As with the polychromatic perspectives, the line drawings have been created by 
students under the editors' tuition during terms at Columbia GSAPP, Tokyo Institute of Technology and ENAC EPFL Lausanne between 2013 and 2015.

The series which results lays out a repertoire of projects, forms, and elements, and it is possible to read the organisational and compositional principles: simple square and rectangular plans that become distorted by repeated set-backs, by obliquely cut corners, by a carefully positioned curved wall; or when cubic volumes combine to form a slab-cube, a tower-cube, a wall-cube; and elements repeat in different projects such as the semi-circular window, the wall reading as a separate surface, large square openings adjacent to small windows. In their presentation as a series, therefore, the many projects become one collective project: a "whole."

\section{Toward the Difficult Whole}

Geers, Pančevac and Zanderigo note the double polemic put forward by Venturi in Complexity and Contradiction: on one hand a turn against the "limitations of orthodox modern architecture and city planning" and on the other hand against the suppression of "complexities and contradictions inherent in art and experience." The editors see the modern project fully realised in what they call the "even covered field" - a hyperdeveloped world that grants ever less space to architecture as a critical and cultural project. To push back against the even field the editors say it is necessary to "reintroduce the cultural narrative" of architecture, to disrupt the even field, a model for which is Venturi's architecture and the critical strategy of "the difficult whole."

\section{Illustration Credits}

arq gratefully acknowledges:

Park Books

\section{Author Biography}

Cameron McEwan teaches at the Institute of Architecture, UCLan, and is a Trustee of the AE Foundation. His research focuses on architecture and the city as a critical project, and is published in Drawing On, Journal of Architectural Education, Lo Squaderno, at the 2014 Venice Biennale, and elsewhere.

\section{Author's address(es)}

Harris Hub

The Grenfell-Baines Institute of Architecture

School of Art, Design and Fashion

University of Central Lancashire

Harris Building, Corporation Street

Preston

PR1 2HE

\section{CAPTIONS:}

[see word document in IMAGES folder] 
The Difficult Whole: A Reference Book on Robert Venturi, John Rauch and Denise Scott Brown.

Park Books, 2016

Edited and with contributions by Kersten Geers, Jelena Pančevac, and Andrea Zanderigo. With photographs by Bas Princen

216 pages, 112 color and $190 \mathrm{~b} / \mathrm{w}$ illustrations

$21 \times 30 \mathrm{~cm}$ (Hardback)

ISBN 978-3-906027-84-5 